
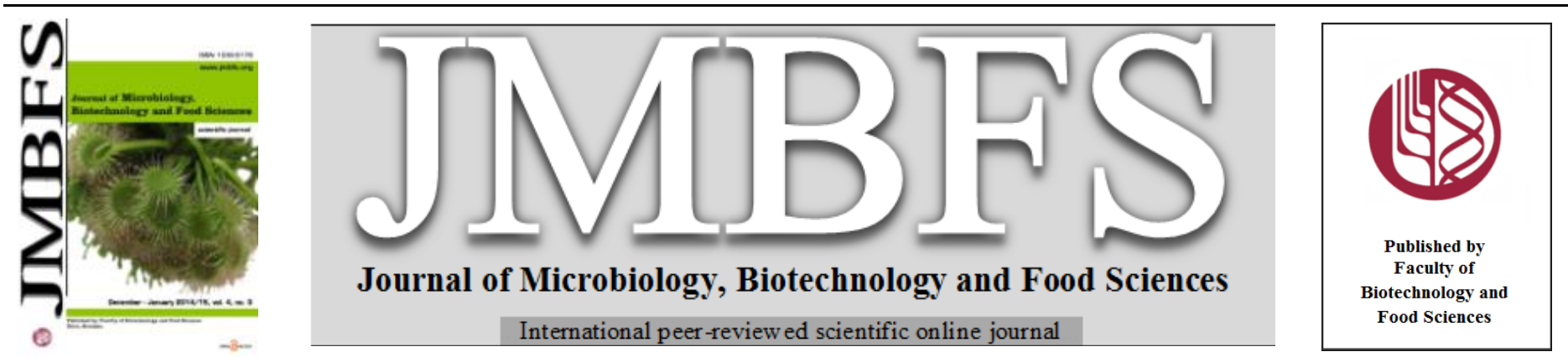

\title{
CELLULASES PRODUCTION UNDER SOLID STATE FERMENTATION USING AGRO WASTE AS A SUBSTRATE AND ITS APPLICATION IN SACCHARIFICATION BY TRAMETES HIRSUTA NCIM
}

\author{
Bhaumik R. Dave, Pritesh Parmar, Ankit Sudhir, Neetu Singal, R. B. Subramanian* \\ Address(es): BRD School of Biosciences, Sardar Patel Maidan, Satellite Campus, P. Box No. 39, Sardar Patel University, Vallabh Vidyanagar 388120, Gujarat, India.
}

*Corresponding author: asp.fus@gmail.com

doi: 10.15414/jmbfs.2014-15.4.3.203-208

\section{ARTICLE INFO}

Received 16. 5. 2014

Revised 24. 9. 2014

Accepted 1. 10. 2014

Published 1. 12. 2014

Regular article

OPEN $\partial_{\text {ACCESS }}$

\begin{abstract}
Food and energy crisis are the biggest constraint all over the world which has focused lights on need of utilizing renewable resources to meet the future demand. A promising strategy is efficient utilization of lignocellulosic waste and fermentation of the resulting sugars for production of desired metabolites or biofuel. Production of all the cellulase enzymes on wheat bran and different parameters regulating it like $\mathrm{pH}$, moisture ratio (substrate: liquid), temperature and inoculum size has been optimized which found to be $4.5,1: 3,30^{\circ} \mathrm{C}$ and $10^{8}$ spores respectively. Salient feature of partially purified enzyme with stability in the range of $30-50^{\circ} \mathrm{C}$ under acidic $\mathrm{pH}$ range was found to be prominent for industrial applications, moreover in this study, Trametes hirsuta, an efficient cellulase producer, was observed to be an effective species for saccharification of wheat straw to enhance the sugar yield. Enzymatic hydrolysis of wheat straw with 15 FPU of cellulase from the species showed $73 \%$ yield in $20 \mathrm{hrs}$. It may prove to be a suitable choice for the industrial saccharification of lignocellulosic biomasses.
\end{abstract}

Keywords: Agro waste, cellulases, solid state fermentation (SSF), saccharification

\section{INTRODUCTION}

The major constituents of the terrestrial plants cell wall is Cellulose which originates from micro-fibrils (2-20nm in diameter and $100-40,000 \mathrm{~nm}$ long). It make up the mesh network of the cell wall. It is a foremost component of natural and mankind produced wastes.

The requirement for expenses of renewable resources to cope up the food and fuel demand has focused the attention towards cellulose use which is the sustainable sources for fuel (Lynd et al., 2002). The major obstacle to the widespread utilization of this important resource is the absence of economically feasible technologies for overcoming the recalcitrant of cellulosic biomass. Hence, there is a considerable economic interest in the development of processes for effective utilization of cellulosic waste as inexpensive carbohydrate sources. A promising strategy for efficient utilization of lignocellulosic waste and fermentation of the resulting sugars for production of desired metabolites or biofuel. The growing concerns about shortage of fossil fuels, the emission of greenhouse gases and air pollution by incomplete combustion of fossil fuel has also resulted in an increased focus on production of bioethanol from lingo cellulose (Sheehan and Himmel, 1999; Zaldivar et al., 2001).

Currently, there are two major ways of converting cellulose to glucose: chemical versus enzymatic. Enzymatic hydrolysis of cellulose is an important reaction in nature for it marks the initial step in cellulose deterioration. One promising approach is to hydrolyze the cellulose to glucose with fungal enzymes and then to ferment the glucose to ethanol which could be used as a liquid fuel (Mandels $\boldsymbol{e t}$ al., 1974). Chemical hydrolysis of cellulosics are of less concern due to the environmental hazards generated with the involvements of acids and alkaline reagents. The research on both methods has for decades occupied the attention of many investigators world wide. Cellulase is a synergistic enzyme that is used to break up cellulose into glucose or other sugar moieties. The fungal cellulase observed to comprise three hydrolytic enzymes: endo-(1,4)- $\beta$-D-glucanase (endoglucanase, endocellulase, CMCase [EC 3.2.1.4]), which cleaves- linkages at any point, mainly in the amorphous region of cellulose, exo-(1,4)- $\beta$-D-glucanase (exocellulase, cellobiohydrolase, cellulose (microcrystalline), avicelase [EC 3.2.1.91]), which releases cellobiose from both reducing or non-reducing end, commonly crystalline parts of cellulose and $\beta$-glucosidase (cellobiase [EC 3.2.1.21]), which releases glucose from cellobiose and short-chain cellooligosaccharides (Bhat and Bhat, 1997).

The production of cellulase and hemicellulases carried out with either solid or liquid state fermentation processes. But Solid state fermentation (SSF) is advantageous over submerged fermentation because of superior enzymes yield, better oxygen circulation and less efforts in downstream procession. The low estimated costs of SSF are due to the rather traditional preferential claim of SSF, viz. SSF can be applied with use of complex agricultural waste substrate and encompassing low-cost technology regarding sterility and regulation demands. However, attempts to reduce costs by using cheap substrates have hampered biotechnological progress in SSF because of the strongly increased diversity in SSF research. There is no consensus on either the methods, the microorganisms or the substrate applied rather it will help to access the system. The broad range of substrates application represents an especially critical problem. One of the key merit of SSF has always been the possibility of using substrates that are abundant, cheap, and not applicable to SmF. It resembles the natural habitat for the filamentous fungi to grow and produce the fermented products. Surprisingly, biological parameters, like enzyme stability of produced enzyme at high temperature or extreme $\mathrm{pH}$, is also shown best in SSF (Deschamps and Huet, 1985; Acuna-Arguelles et al., 1995). Catabolite repression or protein degradation by proteases were severe problems in $\mathrm{SmF}$ often reduced or absent in SSF (Solis-Pereira et al., 1993; Aguilar et al., 2011).

For cellulase production, SSF is most preferred, due to its lower capital investment and lower operating cost (Rodriguez and Anroman, 2005) Additionally, SSF finds greater use in solid waste management, energy conservation and synthesis of secondary metabolites. SSF also allows the use of low-cost agricultural substrates for enzyme production, in turn reduces the production cost. Previously, agricultural residues like wheat bran, wheat straw, rice straw, bagasse, corn stover etc can be applied in production of cellulase. In some cases physical and chemical pretreatments are necessary before the agricultural residues are used for cellulase production, due to their recalcitrant nature.

The report on the production of cellulases by Trametes hirsuta are majority with liquid state fermentation, which needs optimized conditions and sophisticated instruments for the production of cellulases which ultimately adds to the cost of the enzyme production. We report here the production of FPA, CMCase, $\beta$ glucosidase by Trametes hirsuta NCIM. in solid state fermentation using cheap lignocellulosic material, partial purification and characterization of Endoglucanase. The study also focuses on sachharification of wheat straw with crude cellulases. 


\section{MATERIAL AND METHODS}

Fungus

The Trametes hirsuta strain used in the present study was provided by NCIM, National chemical laboratory, Pune, India. It was maintained at $4^{0} \mathrm{C}$ on PDA (Potato dextrose agarose) slants.

\section{Cellulase production under solid state fermentation}

Cellulase production was studied in flasks containing wheat bran as a substrate The basal medium used for moistening agent was $\left(\mathrm{gL}^{-1}\right)$, Peptone 1 , Urea 0.3 , Ammonium sulphate 1.4, Calcium chloride 0.3, Magnesium sulphate 0.3, dipotassium hydrogen phosphate $\left(\mathrm{KH}_{2} \mathrm{PO}_{4}\right) 2,\left(\mathrm{mgL}^{-1}\right)$, Zinc sulphate 1.4 , Cobal chloride 1, Manganese sulphate 1.6, Ferrous sulphate 5 . The basal medium was sterilized at $121^{\circ} \mathrm{C}$ for $15 \mathrm{~min}$ at $15 \mathrm{lbs}$ pressure.

\section{Inoculum}

Inoculum was prepared from 7 days old culture that had been grown on PDA slants at $30^{\circ} \mathrm{C}$. Spore suspension was prepared by adding sterile distilled water containing $0.1 \%$ Tween 80 to each slant and was brushed lightly with a sterile wire loop. Spore count was done using Neubauer's chamber.

\section{Enzyme extraction}

The content of each flask was extracted using $30 \mathrm{ml}$ of $50 \mathrm{mM}$ sodium acetate buffer ( $\mathrm{pH}$ 4.6) and filtered through wet muslin cloth by thorough squeezing. The extract was centrifuged at $8000 \mathrm{rpm}$ for $20 \mathrm{~min}$, clear supernatant was collected and used as crude enzyme for further analysis.

\section{Enzyme assay}

Filter paper assay was used to estimate total cellulase activity in the crude enzyme preparation and endo- $\beta$-1,4-glucanase activity was determined using carboxymethylcellulose (CMC) as the substrate as per the method of Mandels $\boldsymbol{e}$ al. (1975) in which one unit was defined as the amount of enzyme required to liberate one mole of glucose per minute. Reducing sugars in the enzymatic hydrolysate of biomass was estimated by 3,4 dinitrosalicylic acid (DNS) method (Miller, 1959). $\beta$-glucosidase activity was measured as reported by Kubicek (1983) using p-nitrophenyl $\beta$-D-glucopyranoside (PNPG) as substrate and one unit of $\beta$-glucosidase is defined as the amount of enzyme liberating one mole of p-nitrophenol per minute under standard assay conditions. Protein estimation was done by Lowry's (1951).

\section{Effect of $\mathrm{pH}$ on production of cellulases}

The effect of $\mathrm{pH}$ was studied by using different initial $\mathrm{pH} 3.5,4.0,4.5,5.0$ of the fermentation medium. The $\mathrm{pH}$ was adjusted by $1 \mathrm{~N} \mathrm{HCl}$. The flasks were inoculated with solution containing $1 \times 10^{8}$ spores. All flasks were incubated at $30^{\circ} \mathrm{C}$ with intermittent shaking.

\section{Effect of moisture ratio on production of cellulases}

Different moisture ratio (1: 2, 1: 3, 1: 4, 1: 5 as Substrate: Liquid) were used for the production of cellulases. The flasks were inoculated with solution containing $1 \times 10^{8}$ spores. All flasks were incubated at $30^{\circ} \mathrm{C}$ with intermittent shaking and the effect of moisture ratio on enzyme production was studied.

\section{Effect of Temperature on production of cellulases}

To study the effect of different temperature on cellulase production. The flasks were inoculated with solution containing $1 \times 10^{8}$ spores and incubated at different temperatures $20^{\circ} \mathrm{C}, 30^{\circ} \mathrm{C}, 40^{\circ} \mathrm{C}, 50^{\circ} \mathrm{C}$ with intermittent mixing.

\section{Effect of Inoculum size on production of cellulases}

Different inoculum size of fungal culture $\left(1 \times 10^{5}-1 \times 10^{8}\right)$ were studied for the production of cellulases. The flasks were inoculated with solution containing $1 \times 10^{8}$ spores. All the flasks were incubated at $30^{\circ} \mathrm{C}$ with intermittent shaking.

\section{Partial purification of endoglucanase}

Partial purification of the enzyme was performed by ammonium sulfate fractionation method. A calculated amount of ammonium sulphate powder was added to the enzyme extract with constant stirring at $4^{\circ} \mathrm{C}$ to achieve $40 \%$ saturation. After incubation for 2 hour, the content was centrifuged at $12,000 \mathrm{~g}$ a $4^{\circ} \mathrm{C}$ for $30 \mathrm{~min}$. The precipitate was dissolved in minimum volume of Acetate buffer (0.05 M, pH 4.6). Dissolved enzyme was further purified with Sephadex
G-75 column chromatography. The enzyme activity and protein estimation were carried out from the desalted sample.

\section{Gel permeation chromatography}

$5.0 \mathrm{gm}$ of Sephadex G-75 matrix was soaked in five times the volume in double distilled water for overnight swelling. The autoclaved gel matrix was added to the glass column with the dimensions $(1 \times 30 \mathrm{~cm})$. After equilibration of column the sample was loaded and purified fraction of $1 \mathrm{ml}$ volume were collected and used for further study.

\section{Characterization of partially purified Endoglucanase}

\section{Effect of temperature on activity and stability of Endoglucanase}

The optimum temperature for partially purified enzyme was obtained by assaying the relative activity of enzyme at different temperatures $30^{\circ} \mathrm{C}, 40^{\circ} \mathrm{C}, 50^{\circ} \mathrm{C}, 60^{\circ} \mathrm{C}$, $70^{\circ} \mathrm{C}, 80^{\circ} \mathrm{C}$. The thermostability of Endoglucanase was monitored by incubating the enzyme solutions at a fixed temperature, in the range of $30^{\circ} \mathrm{C}$ to $70^{\circ} \mathrm{C}$ for 60 minutes and the activity was deduced after incubation.

\section{Effect of pH on activity and stability of Endoglucanase}

The relative activity of Endoglucanase was determined at different pHs. The optimum $\mathrm{pH}$ of Endoglucanase was determined by preparing the substrate in respective buffers of different $\mathrm{pH}$ ranging from 3 to 8 . Citrate buffer $(0.05 \mathrm{M})$ was used for $\mathrm{pH} 3$, Acetate buffer $(0.05 \mathrm{M})$ was used for $\mathrm{pH} 4 \& 5$, Phosphate buffer $(0.05 \mathrm{M})$ was used for $6-8$. To test the $\mathrm{pH}$ stability, the partially purified enzyme was incubated for 120 minutes at room temperature using respective buffers having $\mathrm{pH}$ range 3 to 8 as described above. The residual activity was estimated by following the standard procedure.

\section{Effect of Metal Ions on Activity of Endoglucanase}

The effect of different metal ions on enzyme activity was determined by incorporating $5.0 \mathrm{mM}$ of $\mathrm{KCl}, \mathrm{CuSO}_{4}, \mathrm{MgCl}_{2}, \mathrm{CoCl}_{2}, \mathrm{HgCl}_{2}, \mathrm{CaCl}_{2}, \mathrm{AgNO}_{3}$, $\mathrm{FeSO}_{4}, \mathrm{MnSO}_{4}$ and $\mathrm{NaCl}$ in to the reaction.

\section{Saccharification studies}

$0.5 \mathrm{gm}$ of delignified substrates such as wheat straw, rice straw and sugarcane bagasse were prepared in Sodium acetate buffer $(0.05 \mathrm{M}, \mathrm{pH} 4.6)$ with $15 \mathrm{FPU}$ of enzyme extract and incubated at $50^{\circ} \mathrm{C}$ for $24 \mathrm{~h}$. Sampling was done at every $4 \mathrm{~h}$ intervals and amount of reducing sugar liberated was calculated.

\section{Delignification of solid substrates}

Twenty gram of chopped rice straw was suspended in $80 \mathrm{ml}$ of $2 \%$ aqueous solution of $\mathrm{NaOH}$ at $85^{\circ} \mathrm{C}$ for $1 \mathrm{~h}$, with solid to liquid ratio as $1: 4$. The solid residue was collected by filtration and washed extensively with distilled water until it reached to neutral $\mathrm{pH}$. The pre treated rice straw was dried in the oven at $70^{\circ} \mathrm{C}$ to maintain constant weight and used as the substrate for saccharification experiments (Jeya et al., 2009).

\section{RESULTS AND DISCUSSION}

\section{Optimization of fermentation parameters}

Regardless of the fermentation process that is used to grow cells, it is necessary to monitor and control parameters starting from the selection of optimum inoculum volume, moisture content, $\mathrm{pH}$, temperature etc. Changes in one of these parameters can have a dramatic effect on the yield of cells and the stability of protein product. The high rate of metabolism supports the critical period of metabolite production. The meaning of optimization in this context needs careful consideration of the environmental and nutritional parameters for growth and production. Solid state fermentation has numerous advantages over submerged fermentation $(\mathrm{SmF})$, including superior productivity, simple technique, less investment, less energy requirement and low waste water generation and better recovery of product (Asgher et al., 2006)

Two major impediments to exploit the commercial potential of Cellulases are yield stability and cost of cellulase production. Therefore, research should be also focus at use of the commercial potential of existing and new cellulase producers (Coral et al., 2002). Generally the substrate exploit in SSF are generally insoluble in water. In practice, water is absorbed onto the substrate particles, which can then be used by microorganisms for growth and metabolic activities. Bacteria and yeast grows on the surface of the substrate while fungal mycelium penetrates into the particles of the substrates (Pandey, 1992). Natural waste materials such as wheat straw, wheat bran and sugarcane bagasse have been effectively utilized as a major carbon source for the production of cellulase enzyme by fungal strains, though the yield is variable, due to effect of substrate 
(carbon source) on the growth of cellulolytic organisms (Mandels, 1985; Zhu et al., 1988; Lakshmikant and Mathur, 1990).

\section{Effect of pH on cellulase production}

The influence of $\mathrm{pH}$ was studied by adjusting the $\mathrm{pH}$ of the medium which is used to wet the substrate. Higher enzyme activities were observed at $\mathrm{pH} 4.5$. Maximum activities for Endoglucanase, $\beta$-glucosidase (BGL) and Exoglucanase (Filter paper activity) were found to be $38.3 \mathrm{U} \cdot \mathrm{gm}^{-1}, 30.86 \mathrm{U} \cdot \mathrm{gm}^{-1}$ and $13.97 \mathrm{U} \cdot \mathrm{gm}$ ${ }^{1}$ respectively (Figure 1). It was observed that an initial $\mathrm{pH}$ of 4.5 was ideal for cellulase production (Xia and Cen, 1999).

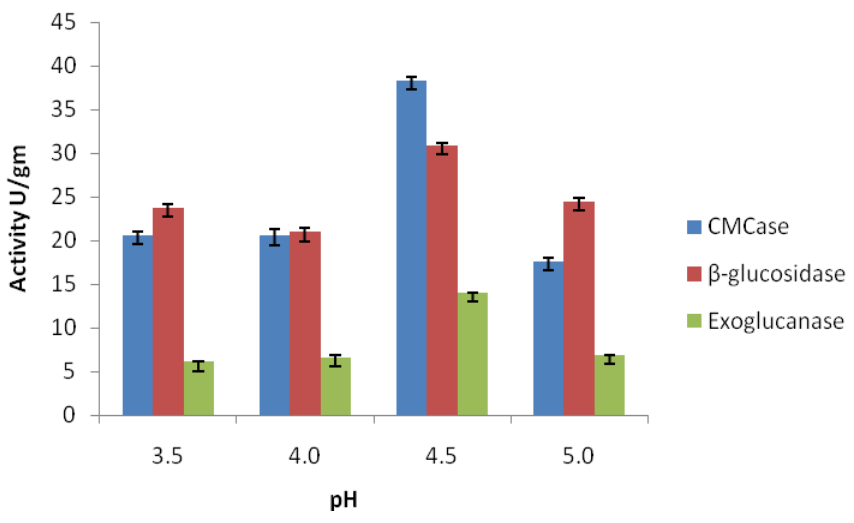

Figure 1 Effect of $\mathrm{pH}$ on production of cellulases by Trametes hirsuta. Enzyme activities were measured according to standard assay conditions and were expressed as Units per gram dry substrate. $(\mathrm{X}$ axis $=\mathrm{pH}$ and $\mathrm{Y}$ axis = Cellulase activity in terms of Units/gm)

Production of most of the fungal cellulases was reported in the $\mathrm{pH}$ range of 4.55.0 (Latifian et al., 2007; Wen et al., 2005). In SSF process, most precaution was taken for optimizing the initial $\mathrm{pH}$ of the medium because of the fact that extracellular enzymes are stable only at a particular $\mathrm{pH}$ and there may be rapid denaturation at lower or higher values (Kalra and Sandhu, 1986). Optimal pH is very important for the growth of microorganism and its metabolic activities. As the metabolic activities of the microorganism are very sensitive to changes in $\mathrm{pH}$, change in $\mathrm{pH}$ affects cellulase production by fungi. On the basis of the data obtained $\mathrm{pH} 4.5$ considered to be suitable for cellulase production by Trametes hirsuta.

\section{Effect of Moisture ratio on cellulase production}

Highest activities of Endoglucanase, $\beta$-glucosidase were observed as $48.49 \mathrm{U} \cdot \mathrm{gm}$ ${ }^{1}, 26.28 \mathrm{Ugm}^{-1}$ with substrate to moisture ratio 1: 3 and Exoglucanase activity $22.81 \mathrm{U}^{\mathrm{gm}}{ }^{-1}$ of substrate with substrate to moisture ratio $1: 2$ (Figure 2).

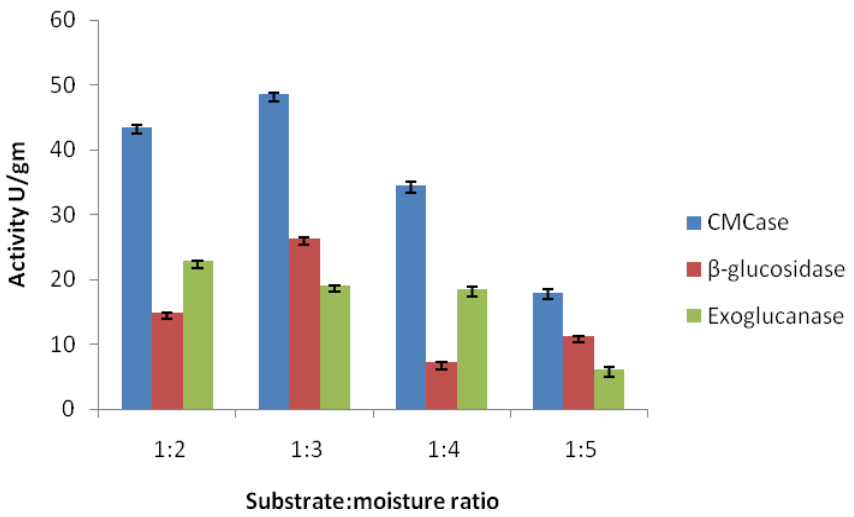

Figure 2 Effect of moisture ratio on production of Cellulases by Trametes Hirsuta. Enzyme activities were measured according to standard assay conditions and were expressed as Units per gram dry substrate.

It was observed that further increase in moisture affects the enzyme production negatively. Ahmed (2008) and Sodhi et al. (2005) reported that moisture content of the substrate is one of the critical factors influencing the outcome of SSF, lower moisture content causes a reduction in solubility of nutrients provided to organism by SSF, a lower degree of swelling and higher water tension. On the other side, reduction in enzyme production at high moisture may be due to the reduction in substrate porosity, changes in the structure of substrate particles, reduction of gas volume and decreasing in microbial growth (Baysal et al. 2003).

Moisture level as an optimizing factor is often neglected in submerged fermentations. In case of SSF it is a critical parameter as the microorganism grows near the surface of the solid substrate particles associated with low moisture content (Raimbault and Alazard, 1980). Transfer of oxygen affects the growth and metabolism, thus, substrate should contain suitable amount of water to enhance mass transfer.

Pandey, (2000) concluded that the degree of hydrate of one of the substrates play an important role on the growth of the fungus and subsequently the enzyme production. Water causes the swelling of the substrate and facilitates good utilization of substrates by the microorganisms. Low moisture may reduce the solubility of lignin and swelling capacity of substrate causing high water stress, and consequently decrease in growth and enzyme production (Raimbault and Alazard, 1980). Increasing moisture level is believed to have reduced the porosity of substrate, thus limiting the oxygen transfer into the substrate (Raimbault and Alazard, 1980). It is also known that the fungus grows and produces maximum enzyme activity at lower water addings.

\section{Effect of Temperature on cellulase production}

Optimum temperature for cellulase production was observed to be $30^{\circ} \mathrm{C}$. As higher Endoglucanase, Exoglucanase and $\beta$-glucosidase activities were found $\left(80.43 \mathrm{U}^{\prime} \mathrm{gm}^{-1}\right.$ and $\left.28.09 \mathrm{U}^{\prime} \mathrm{gm}^{-1}, 33.5 \mathrm{U} \cdot \mathrm{gm}^{-1}\right)$ respectively at $30^{\circ} \mathrm{C}$. Further increase or decrease in the incubation temperature did not result in a corresponding increase in the yield. Thus, high level of cellulase production was noticed at $30^{\circ} \mathrm{C}$ (Figure 3 ).

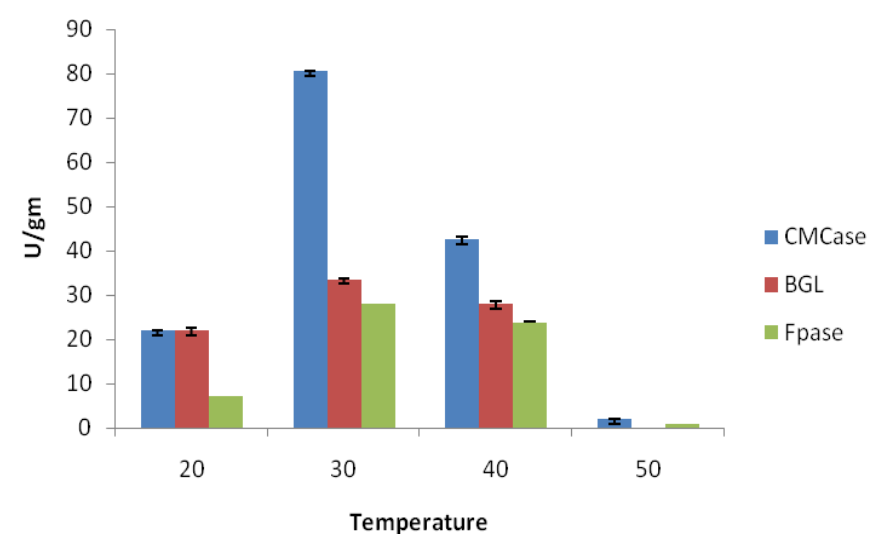

Figure 3: Effect of Temperature on cellulase production by Trametes hirsuta Enzyme activities were measured according to standard assay conditions and were expressed as Units per gram dry substrate. $\left(\mathrm{X}\right.$ axis $=$ Temperature in ${ }^{0} \mathrm{C}$ and $\mathrm{Y}$ axis = Cellulase activity in terms of Units/gm)

Incubation temperature influences the transport of several species of enzyme across the membrane (Poorna and Prema, 2007; Mohana et al., 2008). Maximum enzyme production was recorded at $30^{\circ} \mathrm{C}$ and production was reduced at temperatures higher than $30^{\circ} \mathrm{C}$ (Yang et al., 2006).

\section{Effect of Inoculum size on cellulase production}

It is important to provide an optimal size of inoculum in fermentation cycle, as the lesser inoculum level can result in insufficient biomass and permit the growth of undesirable organism, whereas high inoculum size may produce too much biomass and deplete the nutrients necessary for the production (Pandey $\boldsymbol{e t}$ al. 2003). Irrespective of type of fermentation, whether SSF or submerged fermentation, inoculum size influence the yield of final product greatly (Prakasham et al., 2006).

Maximum activities were observed with inoculum size i.e $1 \times 10^{8}$ spores (Figure 4). With increase in inoculum size, a corresponding increase in enzyme activity was observed. Maximum Endoglucanase, $\beta$-glucosidase and Exoglucanase activities recorded were $90.75 \mathrm{U}^{\prime} \mathrm{gm}^{-1}, 35.7 \mathrm{U}^{\prime} \mathrm{gm}^{-1}$ and $29.02 \mathrm{U}^{\prime} \mathrm{gm}^{-1}$ respectively (Figure 4). The inoculum size can influence the growth of the organism and hence the efficiency of enzyme production and high inoculum size supports adequate growth and eventually efficient enzyme production. 


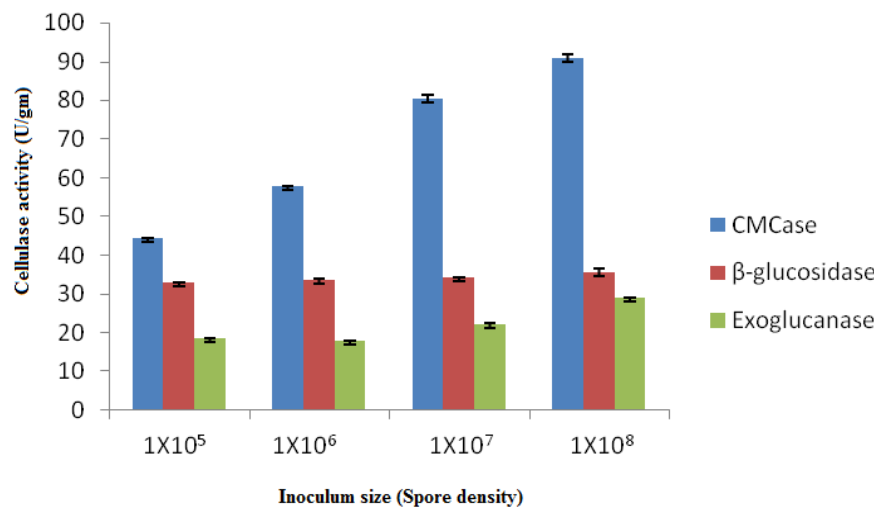

Figure 4: Effect of Inoculum size on production of cellulases by Trametes hirsuta. Enzyme activities were measured according to standard assay conditions and were expressed as Units per gram dry substrate. $(\mathrm{X}$ axis = Inoculum size (Spore density) and $\mathrm{Y}$ axis = Cellulase activity in terms of Units/gm)

\section{Partial purification of Endoglucanase}

A state of high purity is generally not required in processes such as saccharification of lignocellulosic waste. However, it is advisable to remove several unwanted compounds from cell free fraction of culture filtrate. One of the methods used for this purpose is ammonium sulphate precipitation of the selective protein from a mixture of proteins. The ammonium sulphate precipitated fractionation (40\% saturation) followed by gel permeation chromatography of crude cellulases lead to a final recovery of the enzyme, endo$\beta-1,4$-glucanase with increased purity by 5.2 fold. The partially purified enzymes thus obtained were further subjected for characterization studies (Table $1)$.

Table 1 Partial purification of endo- $\beta$-1,4-glucanse

\begin{tabular}{lcccc}
\hline \hline Extract & $\begin{array}{c}\text { Total } \\
\text { Activity } \\
(\mathrm{U})\end{array}$ & $\begin{array}{c}\text { Total } \\
\text { Protein } \\
(\mathrm{mg})\end{array}$ & $\begin{array}{c}\text { Specific } \\
\text { Activity } \\
\text { (U/mg) }\end{array}$ & $\begin{array}{c}\text { Fold } \\
\text { Purification }\end{array}$ \\
\hline \hline Crude & 249.2 & 286.8 & 0.86 & 1 \\
$\begin{array}{l}\mathbf{4 0} \% \\
\text { ammonium } \\
\text { sulphate } \\
\begin{array}{l}\text { Sephadex G-75 } \\
\text { Purified }\end{array}\end{array}$ & 82.5 & 54 & 1.52 & 1.8 \\
\hline
\end{tabular}

\section{Effect of Temperature on Activity and Stability of Endoglucanase}

The effect of temperature on Endoglucanase activity was examined over a temperature range of $30^{\circ} \mathrm{C}-80^{\circ} \mathrm{C}$. Figure 5 shows the enzyme activity which increased gradually with rise in the temperature up to the $60^{\circ} \mathrm{C}$ and decline sharply thereafter. The relative enzyme activities were low at $30^{\circ} \mathrm{C}$, raised to a maximum at $60^{\circ} \mathrm{C}(100 \%)$ and then dropped at $80^{\circ} \mathrm{C}$ to $(61 \%)$. The result shows that the optimum temperature for endo- $\beta-1,4$-glucanase was $60^{\circ} \mathrm{C}$.

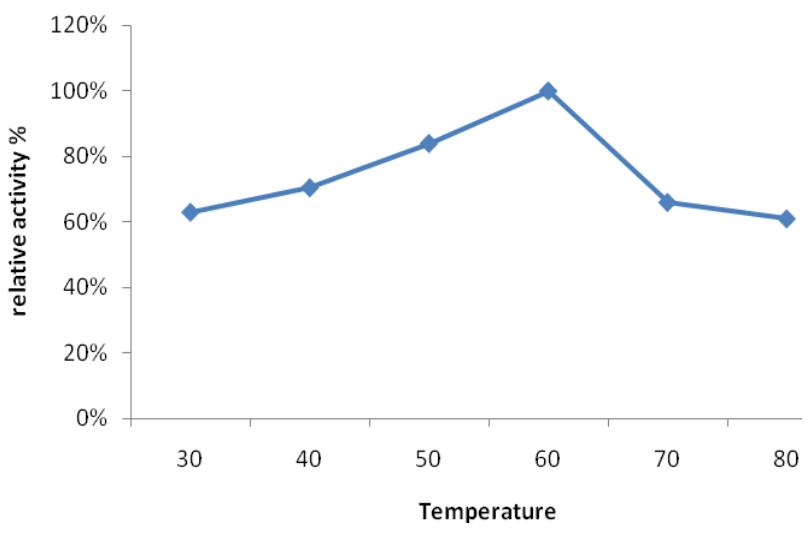

Figure 5 Effect of temperature on activity of partially purified endo- $\beta-1,4$ glucanse of $T$. hirsuta. Enzyme activities measured under standard assay conditions and expressed as relative activity of the maximum. ( $\mathrm{X}$ axis $=$ Temperature in ${ }^{\circ} \mathrm{C}$ and $\mathrm{Y}$ axis $=$ Relative activity in \%)

\section{Effect of Temperature on Stability of Endoglucanase}

Stability of enzyme in the temperature range of $30^{\circ} \mathrm{C}$ to $70^{\circ} \mathrm{C}$ revealed the following observations which are elucidated in Figure 6. Endo- $\beta$-1,4-glucanase was stable up to $50^{\circ} \mathrm{C}$ as the enzyme exhibited nearly $100 \%$ relative activity. These results are in agreement with other reports. However, further increase in the temperature resulted in sharp decrease in the enzyme activity which may be attributed to thermal inactivation of the enzymes.

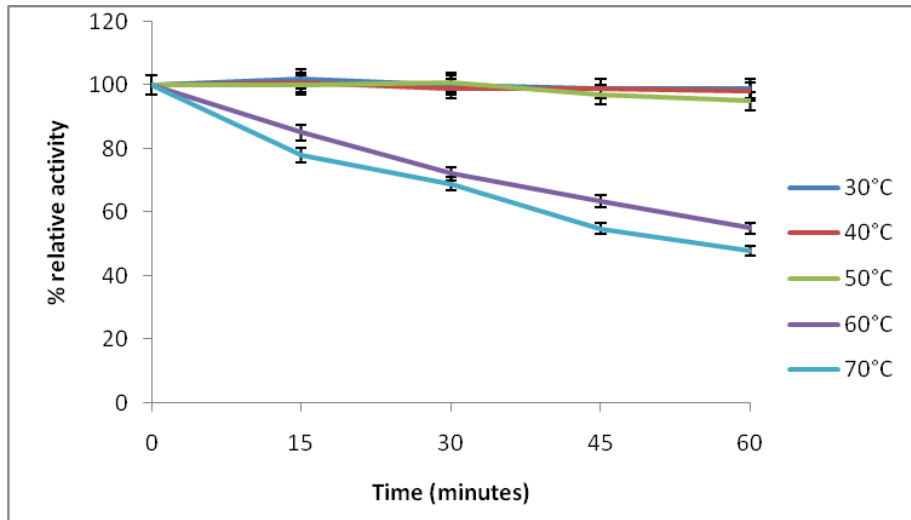

Figure 6 Effect of temperature on stability of partially purified endo- $\beta-1,4$ glucanse of $T$. hirsuta. Enzyme activities measured under standard assay conditions and expressed as residual activity. $(\mathrm{X}$ axis = Time in minutes and $\mathrm{Y}$ axis $=\%$ relative activity)

\section{Effect of pH on Activity of Endoglucanase}

The effect of $\mathrm{pH}$ on Endoglucanase activity was examined by using different $\mathrm{pH}$, ranging from 3-8. The buffers used were $0.05 \mathrm{M}$ Citrate buffer (pH-3), $0.05 \mathrm{M}$ Acetate buffer ( $\mathrm{pH} 4-5)$ and $0.05 \mathrm{M}$ Phosphate buffer ( $\mathrm{pH}$ 6-8) and the enzyme was stable at $\mathrm{pH} 4.5-5.0\left(30 \mathrm{~min}\right.$ at $\left.50{ }^{\circ} \mathrm{C}\right)$. This means that the Endoglucanase from Trametes hirsuta is fairly stable and active at a $\mathrm{pH}$ range of $4.5-5.0$. Figure 7 shows the optimum $\mathrm{pH}$ range for the activity of Endoglucanase is between 4.55.0

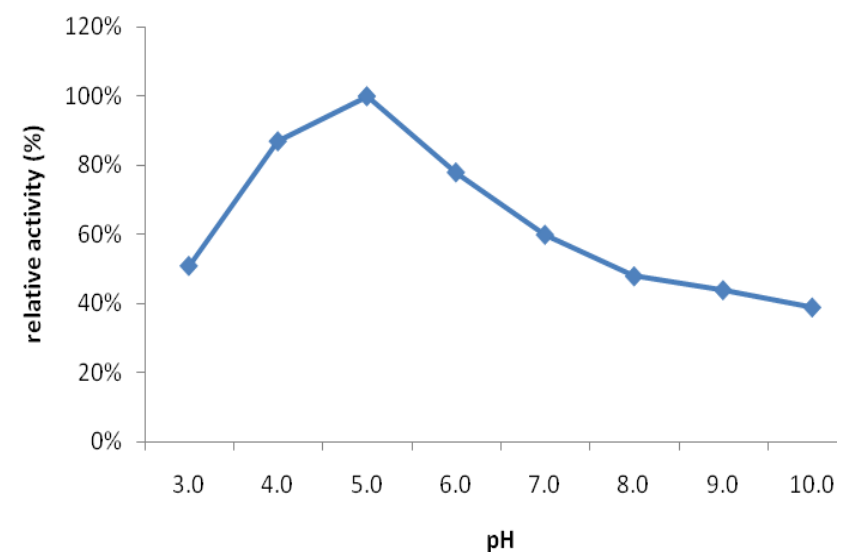

Figure 7 Effect of pH on activity of partially purified endo- $\beta$-1,4-glucanse of $T$. hirsuta. Enzyme activities measured under standard assay conditions and expressed as relative activity of the maximum. $(\mathrm{X}$ axis $=\mathrm{pH}$ and $\mathrm{Y}$ axis $=$ Relative activity in terms of \%)

\section{Effect of pH on Stability of Endoglucanase}

Figure 8 depicts the $\mathrm{pH}$ stability studies in the range of $\mathrm{pH} 3.0$ to 8.0 . It shows that endo- $\beta-1,4$-glucanase was highly stable in the acidic range between $\mathrm{pH} 4.0$ and 5.0 (relative activities $>90 \%$ ). Stability of enzyme decreased with further increase in $\mathrm{pH}$, which was unexpectedly low even at neutral $\mathrm{pH}$. However, changes in $\mathrm{pH}$ resulted in a rapid decline in the enzyme activity, it retained activity at $\mathrm{pH} 8.0$ after $2 \mathrm{~h}$ of incubation, narrating that the enzyme is not stable in the alkaline region. Zhu et al. (1988) found that Endoglucanase was more stable in the range of $\mathrm{pH} 2-5$. 


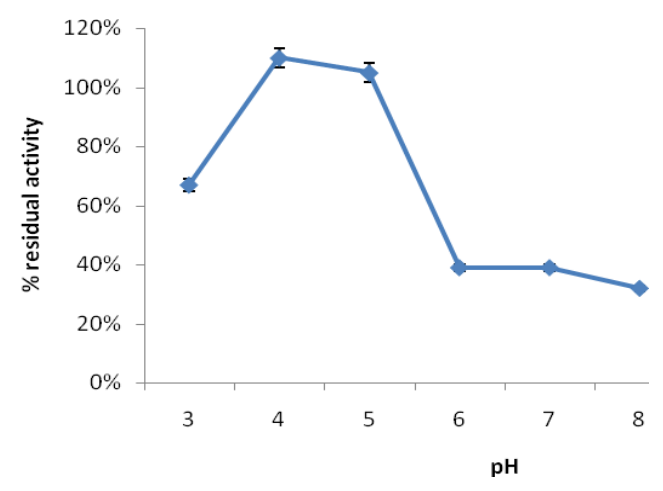

Figure 8 Effect of pH on activity of partially purified endo- $\beta$-1,4-glucanse of $T$. hirsuta. Enzyme activities measured under standard assay conditions and expressed as residual activity. $(\mathrm{X}$ axis $=\mathrm{pH}$ and $\mathrm{Y}$ axis $=\%$ residual activity $)$

\section{Effect of Metal ions on the Activity of Endoglucanase}

Metal ions can be involved in enzyme catalysis in various ways: they may accept or donate electrons; they may bring together enzyme and substrate by coordinate bonds and they may simply stabilize a catalytic active conformation of the enzyme. In the present study, metal ions like $\mathrm{FeSO}_{4}, \mathrm{MgCl}_{2}$ and $\mathrm{NaCl}$ showed positive effect on the activity of Endoglucanase with $\mathrm{AgNO}_{3}$ showing highes relative activity. While $\mathrm{CaCl}_{2}, \mathrm{HgCl}_{2}, \mathrm{CoCl}_{2}, \mathrm{CuSO}_{4}$ and $\mathrm{MnSO}_{4}$ showed inhibitory effect (Table 2).

Table 2 Effect of different metal ions on activity of partially purified endo- $\beta-1,4$ glucanse of T. hirsuta. Enzyme activities measured under standard assay conditions and expressed as relative activity of the maximum

\begin{tabular}{lc}
\hline \hline Metal ions & \% Relative activity \\
\hline \hline Control & 100 \\
$\mathbf{A g N O}_{3}$ & 129 \\
$\mathbf{F e S O}_{4}$ & 116 \\
$\mathbf{K C l}$ & 103 \\
$\mathbf{N a C l}$ & 101 \\
$\mathbf{M g C l}_{2}$ & 100 \\
$\mathbf{C a C l}_{2}$ & 97 \\
$\mathbf{H g C l}_{2}$ & 80 \\
$\mathbf{C o C l}_{2}$ & 75 \\
$\mathbf{C u S O}_{4}$ & 58 \\
$\mathbf{M n S O}_{4}$ & 38.5 \\
\hline
\end{tabular}

\section{Saccharification studies}

Damisa et al. (2008) reported that the pre treatment of substrate with sodium hydroxide may have resulted in the swelling of the particles causing easy removal of the lignin and cellulose depolymerization occasioned by the separation of hydrogen bonds of the cellulose. Generally, the alkali treated residues with low concentration of sodium hydroxide showed higher cellulase yield than the untreated residues. Wheat straw, rice straw and bagasse were pre treated with alkali for delignification.

Figure 9 depicts that wheat straw was found to be the most suitable substrate for hydrolysis with $73 \%$ saccharification after 20 hours as compared to rice straw and sugarcane bagasse. Higher saccharification of lignocellulosics were observed with Trametes hirsuta cellulases using rice straw (Jeya et al., 2009).

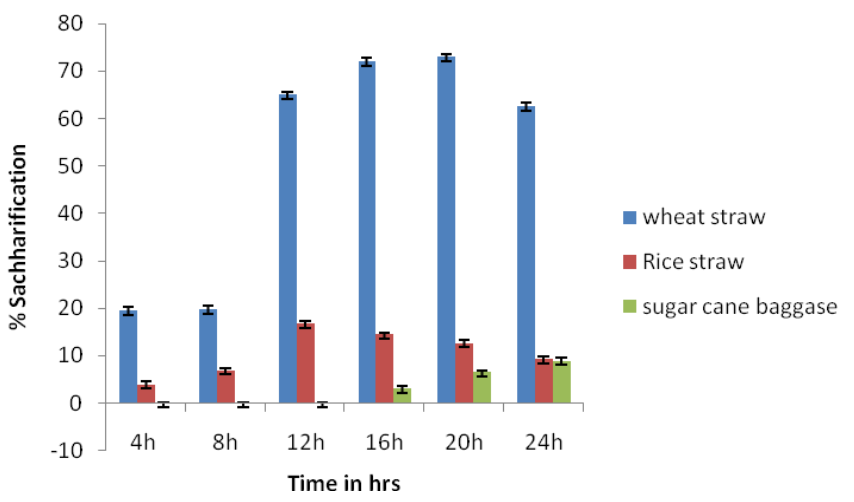

Figure 9 Saccharification of alkali treated substrates. $(\mathrm{X}$ axis $=$ Time in hrs and $\mathrm{Y}$ axis $=\%$ saccharification
Several saccharification studies were reported using different lignocellulosic materials (Hari Krishna and Chowdary, 2000; Zhang and Cai, 2008; Ma $\boldsymbol{e}$ al., 2009; Sukumaran et al., 2009; Yu et al., 2009). Table 3 shows the summary of enzymatic hydrolysis of different substrates. In general, experimental results were enhanced by the optimization using response surface methodology than the conventional optimization methods. Mahat et al. (2004) and Tanyildizi et al. (2006) have reported an increase in production yield to $34 \%$ and $15 \%$, respectively, using response surface methodology. Improvement in the yield and production can also be enhanced using response surface methodology.

Table 3 Comparison of enzymatic hydrolysis of different pretreated substrates by various enzyme sources and the obtained saccharification yield.

\begin{tabular}{|c|c|c|c|}
\hline Source & Substrate & $\begin{array}{c}\text { Sugar released } \\
\text { (mg/gm } \\
\text { substrate) }\end{array}$ & $\begin{array}{c}\text { Saccharification } \\
(\%)\end{array}$ \\
\hline $\begin{array}{l}\text { Trichoderma reesei } \\
Z U-02\end{array}$ & Maize straw & 814 & 83.3 \\
\hline $\begin{array}{l}\text { P. janthinellum } \\
\text { NCIM } 1171\end{array}$ & Baggase & 846 & 94.6 \\
\hline $\begin{array}{l}\text { Celluclast } 1.5 \mathrm{~L}, \\
\text { Novozyme } 188, \\
\text { laccase from }\end{array}$ & Wheat straw & 565 & - \\
\hline $\begin{array}{l}\text { Trametes versicolor } \\
\text { Trametes hirsute } \\
\text { Celluclast, }\end{array}$ & Rice straw & 685 & 88 \\
\hline $\begin{array}{l}\text { Novozyme } 188 \& \\
\text { Viscostar }\end{array}$ & Rice hull & 154 & 90 \\
\hline Trametes hirsuta & Wheat straw & - & 73 \\
\hline
\end{tabular}

\section{CONCLUSION}

Production of all the cellulase enzymes on wheat bran was optimized in progressive manner. Optimum $\mathrm{pH}$, Moisture ratio, Temperature and inoculum size were found to be $4.5,1: 3,30{ }^{\circ} \mathrm{C}$ and $10^{8}$ spores. Partially purified enzyme having stability in the range of $30-50^{\circ} \mathrm{C}$ and in the acidic region was also found to be good for industrial applications moreover in this study, T. hirsuta, an efficient cellulase producer, was established as an effective species for saccharification of wheat straw to yield higher sugars. Enzymatic hydrolysis of wheat straw with 15 FPU of cellulase from $T$. hirsuta resulted in a yield of $73 \%$ after $20 \mathrm{~h}$. T. hirsuta may prove to be a suitable choice for the industria saccharification of lignocellulosic biomasses. Purification and immobilization of cellulase from $T$. hirsuta will further facilitate its application in biomass hydrolysis.

\section{REFERENCES}

ACUNA-ARGUELLES, M.E., GUTIERREZ-ROJAS, M., VINIEGRAGONZÁLEZ, G., FAVELA-TORRES, E. 1995. Production and properties of three pectinolytic activities produced by Aspergillus niger in submerged and solid-state fermentation. Appl Microbiol Biotechnol, 43, 808-814. http://dx.doi.org/10.1007/BF02431912

AGUILAR, C.N., AUGUR, C., FAVELA-TORRES, E., VINIEGRAGONZÁLEZ, G. 2011. Production of tannase by Aspergillus niger Aa-20 in submerged and solid-state fermentation: influence of glucose and tannic acid. $J$ Ind Microbiol Biotechnol, 26, 296-302. http://dx.doi.org/10.1038/sj.jim.7000132 AHMED, S.A. 2008. Optimization of Production and Extraction Parameters of Bacillus megaterium Levansucrase using solid state fermentation. J Appl Sci Res, 4(10), 1199-1204

ASGHER, M., ASAD, M.J., LEGGE, R.L. 2006. Enhanced lignin peroxidase synthesis by Phanerochaete chrysosporium in solid state bioprocessing of a lignocellulosic substrate. World J Microbiol Biotechnol, 22, 449-453. http://dx.doi.org/10.1007/s11274-005-9055-7

BAYSAL, Z., UYAR, F., AYTEKIN, C. 2003. Solid state fermentation for production of á-amylase by a thermotolerant Bacillus subtilis from hot spring water. Process Biochem, 38, 1665-1668. http://dx.doi.org/10.1016/s00329592(02)00150-4

BHAT, M.K., BHAT, S. 1997. Cellulose degrading enzymes and their potential industrial applications. Biotechnol. Adv, 15, 583-620. http://dx.doi.org/10.1016/s0734-9750(97)00006-2

CORAL, G., ARIKAN, B., UNALDI, M.N., GUVENMES, H. 2002. Some properties of crude carboxymethyl cellulase of Aspergillus niger Z10 wild type strain. Turkish J Biotechnol, 26, 209-213.

DAMISA, D., AMEH, J.B., UMOH, V.J. 2008. Effect of chemical pre treatment of some lignocellulosic wastes on the recovery of cellulase from Aspergillus niger $\mathrm{H} 3$ mutant. African J Biotechnol, 7, 2444-2450. http://dx.doi.org/ DESCHAMPS, F., HUET, M.C. 1985. Xylanase production in solid-state fermentation: a study of its properties. App. Microbiol Biotechnol, 22(3), 177180. http://dx.doi.org/10.1007/bf00253605 
HARI KRISHNA, S., CHOWDARY, G.V. 2000. Optimization of simultaneous saccharification and fermentation for the production of ethanol from lignocellulosic biomass. J Agric Food Chem, 48(5), 1971-1976. http://dx.doi.org/10.1021/jf991296z

JEYA, M., ZHANG, Y.W., KIM, I.W., LEE, J.K. 2009. Enhanced saccharification of alkali-treated rice straw by cellulase from Trametes hirsuta and statistical optimization of hydrolysis conditions by RSM. Biores Tech, 100(21), 5155-5161. http://dx.doi.org/10.1016/j.biortech.2009.05.040

KALRA, M.K., SANDHU, D.K. 1986. Optimal production of cellulolytic enzymes and their location in Trichoderma pseudokonigii. Acta Biotechnol, 6(2), 161-166. http://dx.doi.org/10.1002/abio.370060214

KUBICEK, C.P. 1983. $\beta$-glucosidase excretion in Trichoderma strains with different cell wall bound $\beta$-1,3-glucanase activities. Can J Microbiol, 29(2), 163 169. http://dx.doi.org/10.1139/m83-028

LAKSHMIKANT, K. MATHUR, S.N. 1990. Cellulolytic activities of Chaetomium globosum on different cellulosic substrates. World J Micro Biotechnol, 6(1), 23-26. http://dx.doi.org/10.1007/bf01225350

LATIFIAN, M., HAMIDI-ESFAHANI, Z., BARZEGAR, M. 2007. Evaluation of culture conditions for cellulase production by two Trichoderma reesie mutant under solid state fermentation conditions. Bioresour Technol, 98(18), 3634-3637. http://dx.doi.org/10.1016/j.biortech.2006.11.019

LOWRY, O.H, ROSEBROUGH, N.J, FARR, A.L., RANDALL, R.J. 1951.

Protein measurement with the folin phenol reagent. J Biol Chem 31, 426-428.

LYND, L.R., WEIMER, P.J., VAN ZYL, W.H., PRETORIOUS, I.S. 2002 Microbial cellulose utilization: fundamentals and Biotechnology. Microbiol Mo Biol Rev, 66(3), 506-577. http://dx.doi.org/10.1128/mmbr.66.3.506-577.2002

MA, H., LIU, W.W., CHEN, X., WU, Y.J., YU, Z.L. 2009. Enhanced enzymatic saccharification of rice straw by microwave pretreatment. Bioresour Technol, 100(3), 1279-1284. http://dx.doi.org/10.1016/j.biortech.2008.08.045

MAHAT, M.K., ILLIAS, R.M., RAHMAN, R.A., RASHID, N.A.A MAHMOOD, N.A.N., HASSAN, O., AZIZ, S.A., KAMARUDDIN, K. 2004 Production of cyclodextrin glucanotransferase (CGTase) from alkalophilic Bacillus sp. TS1-1: media optimization using experimental design. Enzyme Microb Technol, 35(5), 467-473 http://dx.doi.org/10.1016/j.enzmictec.2004.07.008

MANDELS, M., REESE, E.T. 1985. Fungal cellulase and microbia decomposition of cellulosic fibres. Developments in Ind Microbiol, 5, 5-20.

MANDELS, M., HONTZ, L., NYSTROM, J. 1974. Enzymatic Hydrolysis of Waste Cellulose. Biotechnol Bioeng, 16(11), 1471-1493. http://dx.doi.org/10.1002/bit.260161105

MANDELS, M., STERNBERD, D., ANDREOTI, R.E. 1975. Growth and cellulase production by Trichoderma. In: Bailey, M.; Enari, T.M.; Linko, M. (Eds.), Proceedings of Symposium on Enzymatic Hydrolysis of Cellulose, SITRA Helsinki, 81-109.

MILLER, G.M. 1959. Use of Dinitrosalicylic acid reagent for determination of reducing sugar. Anal Chem, 31(3), 426-428 http://dx.doi.org/10.1021/ac60147a030

MOHANA, S., SHAH, A., DIVECHA, J., MADAMWAR, D. 2008. Xylanase production by Burkholderia sp. DMAX strain under solid state fermentation using distillery spent wash. Bioresour Technol, 99(16), 7553-7564. http://dx.doi.org/10.1016/j.biortech.2008.02.009

PANDEY, A. 1992. Recent process developments in solid state fermentation. Process Biochemistry, 27(2), 109-117. http://dx.doi.org/10.1016/0032 9592(92)80017-w

PANDEY, A., SOCCOL, C.R., MITCHELL, D. 2000. New developments in solid state fermentation: I - bioprocesses and products. Process Biochem, 35(10), 1153-1169. http://dx.doi.org/10.1016/s0032-9592(00)00152-7

PANDEY, A., BOGAR, B., TENGERDY, R.P. 2003. Optimization of cellulase production by solid substrate fermentation. J Ind Microbiol Biotechnol, 30, 183 189.

POORNA, C.A., PREMA, P. 2007. Production of cellulase free endoxylanase from novel alkalophilic themotolerant Bacillus pumilus by solid state fermentation and its application in wastepaper recycling. Bioresour Technol, 98(3), 485-490. http://dx.doi.org/10.1016/j.biortech.2006.02.033

PRAKASHAM, R.S., SUBBA RAO, CH., SHARMA, P.N. 2006. Green gram husk - an inexpensive substrate for alkaline protease production by Bacillus sp in solid state fermentation. Bioresour Technol, 97(13), 1449-1454. http://dx.doi.org/10.1016/j.biortech.2005.07.015

RAIMBAULT, M., ALAZARD, D. 1980. Culture method to study fungal growth in solid fermentation. European J Appl Microbiol Biotechnol, 9(3), 199-209. http://dx.doi.org/10.1007/bf00504486

RODRIGUEZ, C.S., ANROMAN, M.A. 2005. Application of solid state fermentation to ligninilytic enzyme production. Biochem Eng J, 22(3), 211-219. http://dx.doi.org/10.1016/j.bej.2004.09.013

SHEEHAN, J., HIMMEL, M. 1999. Enzymes, energy and the environment: A strategic perspective on the US Department of Energy's research and development activities for biotechnology. Biotechnol Prog, 15(5), 817-827. http://dx.doi.org/10.1021/bp990110d

SODHI, H.K., SHARMA, K., GUPTA, J.K., SONI, S.K. 2005. Production of a thermostable á-amylase from Bacillus sp.PS-7 by solid state and its synergistic use in the hydrolysis of malt starch for alcohol production. Process Biochem 40(2), 525-534. http://dx.doi.org/10.1016/j.procbio.2003.10.008

SOLIS-PEREIRA，S., FAVELA-TORRES，E., VINIEGRA-GONZALEZ，G., GUTIERREZ-ROJAS, M. 1993. Effect of different carbon sources on the synthesis of pectinases in Aspergillus niger in submerged and solid state fermentation. Appl Microbiol Biotechnol, 39(1), 36-41. http://dx.doi.org/10.1007/bf00166845

SUKUMARAN, R.K., SINGHANIA, R.R., MATHEW, G.M., PANDEY, A 2009. Cellulase production using biomass feed stock and its application in lignocellulose saccharification for bio-ethanol production. Renew Energy, 34(2), 421-424. http://dx.doi.org/10.1016/j.renene.2008.05.008

TANYILDIZI, M.S., ELIBOL, M., ÖZER, D. 2006. Optimization of growth medium for the production of a-amylase from Bacillus amyloliquefaciens using response surface methodology. J Chem Technol Biotechnol 81(4), 618-622. http://dx.doi.org/10.1002/jctb.1445

WEN, Z., LIAO, W., CHEN, S. 2005. Production of cellulase/b-glucosidase by the mixed fungi culture Trichoderma reesei and Aspergillus phoenicis on dairy $\begin{array}{llll}\text { manure. } & \text { Process } & \text { Biochem, } & \text { 3087-3094. }\end{array}$ http://dx.doi.org/10.1016/j.procbio.2005.03.044

XIA, L., CEN, P. 1999. Cellulase production by solid state fermentation from the xylose industry. Process Biochem, 34(9), 909-912. http://dx.doi.org/10.1016/s0032-9592(99)00015-1

YANG, S.Q., YAN, Q.J., JIANG, Z.Q., LI, L.T., TIAN, H.M., WANG, Y.Z 2006. High level of xylanase production by the thermophilic Paecilomyces themophila $\mathrm{J} 18$ on wheat straw in solid state fermentation. Bioresour Technol, 97(15), 1794-1800. http://dx.doi.org/10.1016/j.biortech.2005.09.007

YU, J., ZHANG, J., HE, J., LIU, Z., YU, Z. 2009. Combinations of mild physical or chemical pretreatment with biological pretreatment for enzymatic hydrolysis of rice hull. Bioresour Technol, 100(2), 903-908. http://dx.doi.org/10.1016/j.biortech.2008.07.025

ZALDIVAR, J., NIELSON, J., OLSSON, L. 2001. Fuel ethanol production from lignocellulose: A challenge for metabolic engineering and process integration. Appl Microbiol Biotechnol, 56(1-2), 17-34. http://dx.doi.org/10.1007/s002530100624

ZHANG, Q., CAI, W. 2008. Enzymatic hydrolysis of alkali-pretreated rice straw by Trichoderma reesei ZM4-F3. Biomass Bioene, 32(12), 1130-1135. http://dx.doi.org/10.1016/j.biombioe.2008.02.006

ZHU, Y.S.,GAO, H., FEI, J.X., SUM, C.N. 1988. Induction and regulation of cellulase synthesis in Trichoderma mutant EA3-867 and N2-78. Enzyme Micro Techno, 4(1), 3-12. http://dx.doi.org/10.1016/0141-0229(82)90003-5 